\title{
BIRD SPECIES IN DELHI-“BIRDWATCHING” TOURISM
}

\author{
Zeba Zarin Ansari ${ }^{63}$ \\ Ajay Kumar ${ }^{64}$ \\ Anton Vorina ${ }^{65}$
}

https://doi.org/10.31410/itema.2018.161

\begin{abstract}
A great poet William Wordsworth once wrote in his poem "The world is too much with us" that we do not have time to relax in woods and to see birds chirping on trees. According to him we are becoming more materialistic and forgetting the real beauty of nature. Birds are counted one of beauties of nature and indeed they are smile giver to human being. When we get tired or bored of something we seek relax to a tranquil place to overcome the tiredness. Different birds come every morning to make our day fresh. But due to drainage system, over population, cutting down of trees and many other disturbances in the metro city like Delhi, lots of species of birds are disappearing rapidly. Thus a conservation and management system need to be required to stop migration and disappearance of birds. With the government initiative and with the help of concerned NGOs and other departments we need to settle to the construction of skyscrapers. As we know bird watching tourism is increasing rapidly in the market, to make this tourism as the fastest outdoor activity in Delhi, the place will have to focus on the conservation and protection of the wetlands and forests, management of groundwater table to make a healthy ecosystem, peaceful habitats and pollution-free environment for birds. Delhi will also have to concentrate on what birdwatchers require, including their safety, infrastructure, accessibility, quality of birdlife and proper guides. A little struggle and effort is needed to make the extreme changes, which will create well maintenance of the bird species for future bird lover tourist.
\end{abstract}

Keywords: Bird species, problems, conservation, management, bird watching tourism

\section{INTRODUCTION}

$\mathrm{E}$ arly morning, sunrise, fresh air and the sweet calls of the birds makes Delhi a unique place which has its own share of birds and bird lovers. The number of small wetlands and the conserved forests following the Aravalli ranges attracts many areal visitors towards the arid topography of Delhi. After Nairobi in Kenya, Delhi used to be the world's second most bird-rich capital city due to its forest cover and wetlands in its surroundings. The number of bird watching destinations in and around Delhi, which attract the bird lovers are the "Okhla Bird Sanctuary", "the Delhi Ridge", "Sultanpur National Park", "Surajpur Wetlands", "Asola Wildlife Sanctuaries", "Basai Wetlands". The extent of Okhla Bird Sanctuary is four square kilometres. It is located at the door of Noida in Gautam Budh Nagar at Uttar Pradesh. River Yamuna is passing by the OBS leaving the territory of Delhi and enters Uttar Pradesh. More than 320 bird species can be seen here in OBS with 20 water bird species, 44 woodland species, and 43 migratory water birds. The green Delhi Ridge forest is truly a gateway for reserved birds and other animals for bird watchers and wildlife lovers. The life of birds in this

\footnotetext{
${ }^{63}$ National Research Tomsk State University, Lenin Ave, 36, Tomsk, Tomskaya Oblast, 634050, Russia

${ }^{64}$ Jawaharlal Nehru University, New Mehrauli Road, Munirka, New Delhi, Delhi 110067, India

${ }^{65}$ Shool of Economics, Vocational College Celje, Mariborska 2, 3000, Celje, Slovenia
} 
ridge are rich with seasonal and of various types like Rose Finch, Green Heron, Woodpeckers, Booted Eagles, etc., which are among the 200 bird species found in this region. The beautiful Sultanpur National Park which is also called as Sultanpur Bird Sanctuary is situated 1 hour distance from South Delhi and half an hour from Gurgaon is a vast marshy land with varied bird species of resident and migratory birds like little Egret, Black Necked Stork, Weaver Bird, Eurasian collared dove, Cattle Egret, Siberian Cranes, Greater Flamingo, etc. This park is a heaven for birds and also bird watchers. Surajpur wetland is situated on the fringes of Greater Noida. It is a biodiversity park where birds like Asian Openbill Stork, White-necked Stork, Black-crowned Night Heron and Black-headed Ibis, rare birds like Bristled Grassbird, Blacknecked Stork and Sarus Crane, etc., are found. This park has 186 species of birds belonging to 44 families. Asola-Bhatti wildlife sanctuary is situated at the south of Delhi, at Asola near Tughlaqabad in Delhi. 193 species of birds are seen here in the sanctuary. Biogeographically it is a best place for restoration of bird species. Basai Wetland is situated in the Gurgaon District of Delhi NCR. This wetland conserves high diversity of birds with at least 282 bird species recorded of 2017. This wetland is the hotspot for birding. Tourists and Media come here to have E-photography and to make documentary movies for channels, advertisements and publications. Red headed Vulture, cattle egret, greater flamingo, water pipit, common crane etc. are the beauty of Basai Wetland. Due to rapid civilization of human beings, the wetland has become a major threat for birds and other animals. Due to unsustainable development and rapid urbanization, the wetlands, open forests and pastures are in danger zone for the survival of varied bird species. Agricultural lands are also transformed into an industrial land which is causing pollution to air and underground water-table, causing threat for bird's survival. As the biodiversity is in tremendous loss, conservation and management is needed for better sustainable tourism.

\section{LITERATURE REVIEW FOR RESEARCH}

We have studied selected literatures for the present paper. We have noticed several observations of different researchers in the given field. Given literature has suggested numerous methods to preserve and save migratory and local birds. We have learnt from different monitoring systems used in other countries. For the literature review, we are giving names of selected articles.

1. (http://ceur-ws.org/Vol-1498/HAICTA 2015 paper54.pdf) Bird watching and Ecotourism: An Innovative monitoring system to project the Species of Lesvos Island to Potential Ecotourists. Chryssoula Chatzigeorgiou, Ioanna Simelli, Apostolos Tsagaris. - The given work comprises with rare species of birds in Lesvos Island. The place is known for birds, and meant especially for the tourists who love to watch different words. This article also tells about the active and passive eco-tourism and also teaches us how to save it. [19]

2. (http://www.diva-portal.org/smash/get/diva2:706189/FULLTEXT01.pdf ) A Bird watching Database System. By. Conny Andersson. Department of Information technology, Uppsala University, Uppsala, Sweden. 2013. - The article refers to the bird watching database in order to analyse different developments and new trends for the populations of birds. The article has a vital information with the tables of database of birds species. [20]

3. (https://indiabiodiversity.org/biodiv/content/documents/document-8d97689a-1553455f-a4df-c7cee6821890/486.pdf ) The book of Indian Birds by Salim Ali. Publ. The Bombay natural history society, Bombay, India. 1941. - The book describes the descriptions and illustrations of common and uncommon Indian birds. The book also provides the scientific names of the local birds as their names can be vary from area to area. The book has helped us to find out names and differences of local birds. [21] 
4. (https://www.researchgate.net/publication/305307630_A checklist of the birds_of_I ndia/download) A checklist of the Birds of India by Praveen J., Rajah Jayapal and Aasheesh Pittie. The research paper witnesses records of the selected birds species within the Indian political boundaries. In the paper we have noticed data of counted birds species with the geographical land area of Republic of India. This update of birds species will help us to locate the some of the birds species with their dwelling area. [22]

5. (http://www.moef.nic.in/downloads/public-information/Chap-2-new.pdf)

Identification manual on Birds by Ministry of Environment and Forests - This is a manual of Exotic and Indian birds with their specifications. In this manual we read the categorizations of birds species on names, identifications, legal status, trade and affected states. We find out some common and special species of birds with the coloured image. This given manual helped us to see the status of birds in the above given category. [23]

\section{STUDY AREA}

Delhi is located at 23.38 degree north and 77.13 degree east in the Northern part of India and bounded by Haryana State on the Northwest and South, Rajasthan state on the Southwest and Uttar Pradesh state on the east. The metropolis city is demarcated into three parts with the Gangetic plains forming the major part, the Yamuna flood plain and the Delhi ridge. The flood plain is filled with rich and fertile alluvial soil. The land stretches about $51.9 \mathrm{~km}$ long and 48.48 $\mathrm{km}$ wide. Delhi does not follow any specific pattern geographically and it is widely erratic fields in the north to the dry parched hills which branches out of the Aravalli Hills of Rajasthan in the south. The extreme end of Delhi spans from Sarup Nagar in the northern part to Rajorki in the southern part. Towards the extreme west is Najafgarh and extreme east is the holy Yamuna River, Shahdara and Bhajanpura which are major shopping centres. The main city of Delhi ends in Saket on the south and central northern area is Connaught Place whilst the western boundary limits at National Highway - 8. [7]

\section{Figure: India map showing part of Delhi through GIS software}

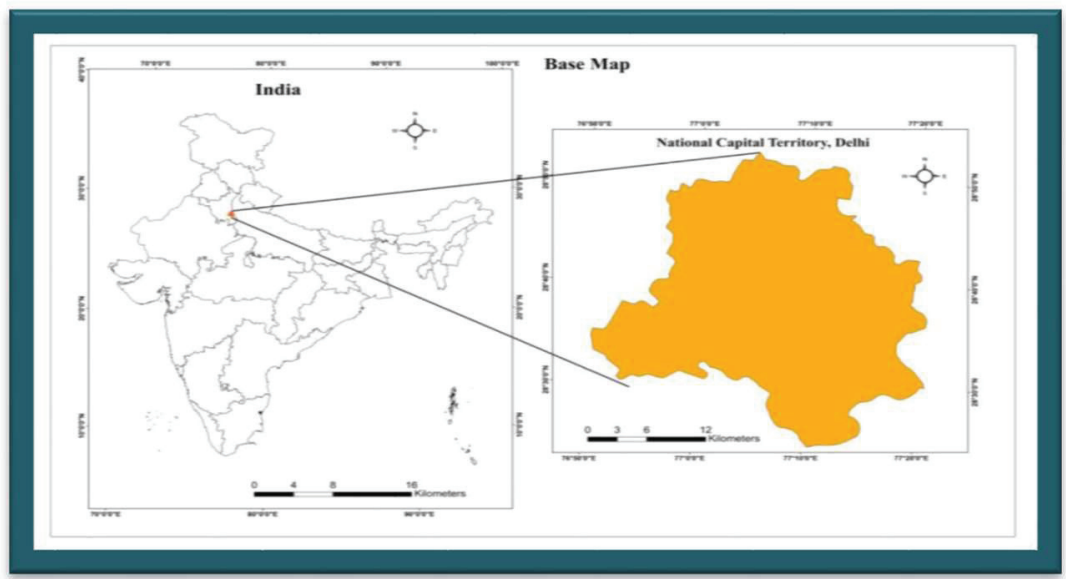




\section{OBJECTIVE}

- To study the conservation pattern of the area.

- To study the present problems of the conservation of birds of the given area.

- To find out the better solution and policies to conserve and manage the bird species for better bird watching tourism.

\section{METHODOLOGY}

- Primary data from the Ministry of Environment, Delhi.

- Primary data from the field survey report.

- Appliance of Arc GIS software to show the study area.

- Appliance of statistical techniques to study the birds of the area.

- Secondary data from the District Census Hand Books, newspapers, internet sources, wildlife books and magazines, officials and semi-officials published reports, research articles and works of individual scholars.

\section{ANALYSIS AND DISCUSSION}

Many different species of migratory birds travel here for nesting during the winter and enjoy the weather up to the offspring, which makes the site colourful and beautiful. Many tourists gather to discover the colourful birds that nestled along the hidden place. For some of them bird watching is not only the hobby but also it is a mental satisfaction and fulfilment of capturing the memories of the beautiful birds in the camera which is incredible and truly indescribable. Only the bird lovers know the techniques of watching the birds in the bushes and jungles. They have the thrill of observing the movements in the forests or on the trees and run after the call of the birds or stick patiently under the tree where they have nested.

Delhi is facing zero sparrow species, which were once home to Delhi. The reason is tall buildings, over population, industries and factories and the most critical problem, which are killing the sparrows, is the mobile phones and mobile towers. The radiation is the big issue going on which is decreasing the migratory birds and the local birds. Today not a single sparrow can be seen in Delhi NCR.

Special sightings of rare birds in Delhi NCR from 2013 to 2018 are shown below:

Yamuna Biodiversity Park spread over 457 acres. Special sightings - Grey-headed lapwing, mallard, ferruginous pochard, red-crested pochard and garganey.

\begin{tabular}{|c|c|}
\hline YEAR & SPECIES SPOTTED \\
\hline 2018 & 104 \\
\hline 2017 & 103 \\
\hline 2016 & 91 \\
\hline 2015 & 109 \\
\hline 2014 & 95 \\
\hline 2013 & 100 \\
\hline
\end{tabular}

Kamla Nehru Ridge spread over 200 acres. Special sightings - Woodshrike and White-eared Bulbul 


\begin{tabular}{|c|c|}
\hline YEAR & SPECIES SPOTTED \\
\hline 2018 & 45 \\
\hline 2017 & 55 \\
\hline 2016 & 57 \\
\hline
\end{tabular}

Tughlakabad Biodiversity Park spread over 200 acres. Special sightings - Sirkeer Malkoha and Common Woodshrike.

\begin{tabular}{|c|c|}
\hline YEAR & SPECIES SPOTTED \\
\hline 2018 & 53 \\
\hline 2017 & 26 \\
\hline
\end{tabular}

Tilpath Valley Biodiversity Park spread over 172 acres. Special Sightings - Yellow Wattled Lapwing and yellow-eyed Babbler.

\begin{tabular}{|c|c|}
\hline YEAR & SPECIES SPOTTED \\
\hline 2018 & 42 \\
\hline 2017 & 26 \\
\hline
\end{tabular}

Common Pochard is now rare in NCR. But (International Union for Conservation of Nature) IUCN's latest report is proof of how wetlands here are either disappearing or are not able to support aquatic and bird life any more. The IUCN red list now has a total of 180 bird species in India in the threatened category as against 173 last year. In NCR, several water bodies are polluted to support plant life. In parts of the Yamuna, there is no Hydrilla or vallisneria and other aquatic plants which many water birds feed on. "This is a very worrying report. Northern lapwing, a beautiful green bird, prefers marshlands. If you notice, marshlands are being encroached rapidly by infrastructure projects. The steppe eagle likes feeding on reptiles and insects but its food is depleting. Diclofenac use is severely impacting the raptors, "said Faiyaz A Khudsar, scientist in charge, Yamuna Biodiversity Park. BNHS in its statement said, "Older BNHS studies had revealed that just like steppe eagle three vulture species--white-backed, slenderbilled and long-billed--have been severely affected by veterinary diclofenac. Subsequent research had also highlighted the diclofenac threat to red-headed and Egyptian vulture.

According to Bikram Grewal the Okhla Bird Sanctuary has recorded around 350 great cormorants by the second week of November 2018 compared to 450 in 2017 and 475 in 2016. Similarly, only three northern shovellers have been recorded against 18 in 2017, which itself was a huge drop from 96 in 2016. The same can be said about common pochards - only two have been seen in 2018 against 21 in 2017 and 77 in 2016. The park has also recorded arrival of five northern pintails compared to seven in 2017 and 28 in 2016, and that of three gadwalls against 24 in 2017 and 142 in 2016 . "We have seen a sharp drop in numbers compared to 2016 and a slight drop against last year's counts. The pollution and the resultant haze could be affecting them. We have seen shovellers do a recce of the waterbody but they did not return after that and may have proceeded to parts of Haryana," said Faiyaz Khudsar, scientist in charge at the park. During winter, pollutants get trapped, making it difficult for the birds to identify their sites, he added. Jaswinder Waraich, another birder, said locations like Okhla, Yamuna Khadar and Dhanauri had recorded a drop, but some are reporting good sightings. "They have taken time to arrive and the numbers are slowly picking up in NCR," said Waraich. NCR has recorded a drop in overall bird species on the Big Bird Day - an annual birding event across the region where birders set out to record different species with 238 species counted in 2018 as compared to 268 in 2017. Bird species across different locations in the capital also recorded a 
slight drop compared to last year; however, there has been significant increases in locations like Tughlakabad, Tilpath Valley and Okhla bird sanctuary when compared to data from last year. The important sightings recorded this year included the oriental scops owl - last seen in 2011 on the outskirts of NCR and extremely rare for the region; a brown-hawk owl which was sighted at Asola and a pair of grey-headed lapwing at the Yamuna Biodiversity Park. "We are studying if the migratory owl species have become residents in the capital or not," said Dr Surya Prakash, zoologist, JNU. Birders across the region feel the overall drop in numbers could be due local climate change which may be affecting the migratory pattern of certain species, forcing them to leave early. "By this time last year, a lot of the species hadn't left but this time temperatures have been very high and a few species have left. There has been little rainfall this winter and the temperature has been warmer than normal which could have resulted in this drop," said Nikhil Devasar, organiser of the event. According to the results, bird species almost doubled at Tughlakabad this year, increasing from 26 last year to 55 this time around while Tilpath Valley recorded 42 species this year as compared to 26 last year. Faiyaz Khudsar, scientist in-charge at the Yamuna Biodiversity Park, said the increase at these locations could be due to better protection. "Grazing at Tilpath and Tughlakabad was reduced this year which has protected the scrublands and resulted in an increase in insect and invertebrate diversity. This in turn attracts more bird species to the area," he said.

Okhla also recorded a significant improvement with 99 species recorded this time around as compared to 71 last year. Team captain Jaswinder Waraich said the increase could be attributed to careful scanning of the area and increased available of food this year. "The important sightings at Okhla this year included booted eagle, mallards, grey bushchat and greater spotted eagle," said Waraich. With the Asian Waterbird Census (AWC) 2018 currently underway in Delhi-NCR, the findings of the first few days at Okhla Bird Sanctuary have revealed that the bird count has almost doubled since 2017. There has also been an increase in the number of species at the sanctuary. This year's count at Okhla Bird Sanctuary revealed 11,622 water birds as compared to 6,183 birds, which were recorded last year. In addition, the number of different species has also risen to 63 as compared to 53 in 2017. These include nine species that fall under the IUCN red-list of threatened species. The Okhla Bird Sanctuary is one of the 466 Important Bird Area sites located in India. The census was carried out by Wetlands International South Asia, in collaboration with Gautam Buddh Nagar Forest Division, and a team of 30 members from different universities and Bombay Natural History Society. AWC Delhi statecoordinator and ecologist TK Roy said that the census has also revealed sighting of two uncommon species at the sanctuary this year - the northern lapwing and the common shelduck. "This a good sign for the ecology of the area. Both birds are not very common to the area. In fact, the northern lapwing has been sighted in India after several years. The count of species has also risen this year and there has been a steady growth in the numbers over the past two years. This shows that there has been a revival at Okhla," Roy told TOI. In 2016, 3,113 birds were recorded at Okhla, which consisted of 46 different species. The same number has increased to 11,622 this year, consisting of 63 different species. The oriental darter, painted stork, black-headed Ibis, common pochard, greater spotted eagle, ferruginous duck, woolynecked stork, northern lapwing and the river lapwing are among the IUCN red-list threatened species sighted at Okhla this year. Roy attributed the considerable increase in number of bird count to more northern shovellers arriving at Okhla in 2017, along with a mixed flock of blackheaded and brown-headed gulls. "These birds would earlier spend their day around Yamuna and come to Okhla at night. This year, however, they are staying at Okhla all day. This has resulted in an increase in the overall count of birds," Roy added. The numbers could have been even more, Roy said, but for the repair work at Okhla barrage in October, which saw a number of waders leave the sanctuary. The census, which continued till January 21, covered other 
locations like the Yamuna floodplains, Delhi zoo, Sanjay Lake, Najafgarh drain and Surajpur wetlands. Hundreds of birders gathered at wetlands, forests and biodiversity parks of the capital to spot and document as many bird species as possible. They were participating in Big Bird Day 2018, an annual national event started by a birding group, Delhi bird. About 38 teams from Delhi-NCR participated in the event, each having 10-40 birders. The results, which will take a couple of days to be compiled, play a crucial role in documenting the number of birds and diversity in the country. In all, more than 10,000 birders from across the country participated. In Delhi-NCR, birding sites like Dighal, Sultanpur, Basai, Asola, Najafgarh, Yamuna Khadar, Mangar Bani, Dhanauri, Dadri, Okhla Bird Sanctuary, Aravalis, Yamuna Biodiversity Park etc. were explored. "It's very difficult to give the trends right away. We haven't got any reports of exceptional sightings from Delhi-NCR yet," said Nikhil Devasar, one of the organisers who spent a part of the day at Dighal. Yamuna Biodiversity Park recorded 104 species this year as compared with 103 last year. Rare sightings included the Grey-headed lapwing, Ferruginous pochard, mallard, Red-crested pochard and garganey. "The Grey-headed lapwing is an important sighting and we have been seeing for two weeks now. It is a rare bird for Delhi...the count also helps us to know the right habitat and environment. A high count of bird's means that the habitat is thriving," said Faiyaz A Khudsar, scientist in charge, Yamuna Biodiversity Park.

At Kamla Nehru Ridge, the number of species spotted went down to 45 in 2018 from 55 in 2017. Woodshrike and White-eared bulbul were the rare sightings in the area. However, numbers at Tughlakabad Biodiversity Park and Tilpath Valley rose significantly in 2018 to 52 and 43 species recorded respectively as compared with just 26 species at each of the locations in 2017. The sightings at these locations included a Sirkeer malkoha, common woodshrike, Yellow wattled lapwing and Yellow-eyed babbler, among others. M Shah Hussain, scientist in charge at Aravalli Biodiversity Park said, "A total of 900 birds of 79 species were spotted during the count period. Important bird species that were seen in Aravalli Biodiversity Park included Jungle bush quail, Eurasian eagle owl and Oriental skylark". He added, "Tufted duck was also sighted at Neela Hauz Biodiversity Park after its restoration. The highlights, Jungle bush quail and Eurasian eagle owl, are rare for south Delhi". Sharp fall in Numbers over Last Year at Yamuna Floodplains. The population of waterbirds in the Yamuna floodplains has gone down considerably this year, though the number of species sighted rose from last year's 23 to 32 this time around, the latest findings of the Asian Waterbird Census (AWC) 2018 have shown. The number of water and water dependant birds were recorded at 594 in 2018 - a sharp drop from the 2,640 birds last year, which experts attribute to human interference on the floodplains, climate change and pollution. "Due to global climate change, shrinking wetland habitats and changing trends of long distant winter migratory birds, there has been a reduction in the numbers at Yamuna. Last year, the majority of these numbers consisted of black-headed gulls, which have now gone to Okhla this year," AWC state coordinator TK Roy told TOI. The census, which was simultaneously being conducted across 27 countries, were conducted at Yamuna floodplains between Wazirabad barrage and the Nizamuddin Bridge on January 13, by volunteers from several universities, Greenpeace, experienced birders from Delhi and the AWC Delhi state coordinator and ecologist, TK Roy. Last year's census recorded 1,996 black-headed gulls at the Yamuna floodplains; however these numbers fell to just 99 this year. Among the other birds which fell in numbers were the common sandpiper, great cormorant, whiskered tern and ruff. Roy said that out of the 32 species, only the river lapwing is classified as threatened according to the IUCN red list, which rose from 10 last year to 12 this time. The count identified 13 species from the 32 as resident water birds, with the remaining 19 as winter migratory birds. The AWC in 2016 had recorded 24 species with 598 birds in total. The AWC began on January 6 in Delhi and continued till January 21. Among the areas covered, include the Okhla Bird 
Sanctuary, Najafgarh drain, Yamuna floodplains, Delhi zoo, Sanjay Lake and Surajpur wetlands. Findings at Okhla had shown that the number of birds has almost doubled in 2018, increasing from 6,183 birds in 2017 to 11,622 birds in 2018. Roy said the final phase of the census is currently underway at Delhi zoo, with the results likely to be out in the next few days. It was a fruitful morning for birders as 18 different teams set out across different parts of Delhi NCR for the 3rd annual edition of the summer bird count, results of which came out. A total of 174 species were recorded in 2018- a sharp drop from the 195 species which were recorded in 2017. However birders attributed this to an early summer and the fact that the count was organised by the end of May instead of early May, so no "winter migrants" were recorded. "In the previous years, the summer bird count was held in early May and we usually had 35-40 lingering winter migrants making it to our total species count. To avoid that, we have held the count much later in 2018 and therefore we have seen a drop in the number. As a result only 10 lingering migrants were recorded," said Kanwar B Singh, a birder and organiser of the event. Singh said that 90 birders took part last year, including two teams consisting only of children. A team led by Brigadier Arvind Yadav covered the bird habitats along the Najafgarh drain, with a total of 108 different species recorded there, including the oriental pratincole that breed there during the summer months. The team also managed to sight a ruddy-breasted crake - an uncommon bird usually found in the reed beds. At the Yamuna floodplains, a total of 90 species were recorded which included summer breeding residents like little tern, cotton pygmygoose, white-tailed stonechat and river lapwing among others. For the first time in the count, the neighbouring district of Rewari was also covered with a team led by Dr Parikshit Yadav recording 103 species. A number of uncommon and important sightings were also made in Mangar and Damdama Lake which included the sighting of the Indian pitta - a breeding visitor to forest patches in the area.

August 26, 2018, morning brought cheer to the community of birders in Delhi-NCR, after a rare migratory bird, the Rufous-tailed Scrub Robin, was sighted at the Aravali Biodiversity Park. The bird was spotted for the first time in the Aravali Biodiversity Park last year. According to birders, sightings during the same time of the year (for two consecutive years) might indicate the bird has made Gurgaon its monsoon migratory destination. However, in 2018 they have again spotted the bird in the same month. This gives them hope that Aravali Biodiversity Park habitat is inviting the bird, and that Gurgaon could be its monsoon migration destination," said Amit Sharma, an avid birder who spotted the bird along with two other enthusiasts, Gaurav Yadav and Janardan Barthwal. Birder Gaurav Yadav, from DLF Phase 4, said, "I have been birding for the last two years. It's very rare that one sees a Rufous-tailed Scrub Robin here." As per birders, the Aravali Biodiversity Park has done a great job in growing and maintaining native species of the Aravalis, which is now attracting birds. Pankaj Gupta of NGO Delhi Bird Foundation agreed, saying, "Native plantation in the Aravali Biodiversity Park is definitely paying off in protecting and inviting rare species. It provides a safe habitat to birds. Food is also in abundance." While the Rufous-tailed Scrub Robin has been recorded in scrub forests of Rajasthan and Gujarat, there are only 3-4 sighting records of the bird in the last 10 years in Delhi-NCR. Some 2-3 years ago, there were reports of the bird being sighted in Dadri and Surajpur areas of Noida. Vijay Dashmana, chief ecologist at the Aravali Biodiversity Park said, "The sighting shows that we need more city forests to conserve flora and fauna of the Aravalis." 
Numbers at Yamuna Biodiversity Park:

\begin{tabular}{|l|c|c|c|}
\hline SPECIES & $2016-2017$ & $2017-2018$ & $2018-2019$ \\
\hline Great Cormorant & 475 & 450 & 350 \\
\hline Northern Shoveller & 96 & 18 & 3 \\
\hline Common Pochard & 77 & 2 & 2 \\
\hline Northern Pintail & 28 & 7 & 5 \\
\hline Gadwall & 142 & 24 & 3 \\
\hline Tufted duck & 11 & 9 & 3 \\
\hline
\end{tabular}

Blame to climate change for number of species found in Delhi NCR:

\begin{tabular}{|l|c|c|}
\hline & \multicolumn{2}{|c|}{ SPOTTED SPECIES } \\
\hline LOCATION & 2017 & 2018 \\
\hline Dighal & 167 & 165 \\
\hline Najafgarh jheel & 160 & 156 \\
\hline Sultanpur & 129 & 120 \\
\hline Okhla Bird Sanctuary & 71 & 99 \\
\hline JNU & 90 & 94 \\
\hline Dhanauri & 85 & 96 \\
\hline Garhi Mandu & 51 & 44 \\
\hline Yamuna Biodiversity Park & 103 & 104 \\
\hline Kamla Nehru Ridge & 55 & 45 \\
\hline Tughlakabad & 26 & 55 \\
\hline Tilpath Valley & 26 & 42 \\
\hline Asola & 95 & 94 \\
\hline
\end{tabular}

\section{CONCLUSION}

The conclusion part of the present research consists of the present scenario of the endangered species of birds in the given wetlands or in the bird century. We have deeply read the observation and research of the others bird lovers in India; those put their sorrow to the pathetic decreasing condition of the birds in Delhi-NCR. As we have discussed about the disappearance of home sparrow in large number. We can find them only in the forest area and with some number. The reason of disappearance of many local birds come under the modern infrastructure of official as well as residential buildings. Local birds hardly find space for their nest and rest in the evening. Maximum increase of vehicles in the residential area disturb the tranquillity of birds as the vehicle sound interrupt their communication and dwelling conditions. New technology has diverted their sense of understanding directions. Government is sanctioning new mobile companies and these telecommunication companies keep increasing and decreasing mobile radiations as per their comfort and benefit. A bird can travel thousands of miles without any scientific methods. It naturally has a sense of finding suitable direction. However, the birds lost their directions because of radiations from mobile tower. Even rays from mobile phones kill them. If we estimate the consequences of radiations from the mobile tower, so we can imagine it with somebody who stand under the tower even for a few seconds. The radiations will make paralyzed him with several health issues. Thus, we must think over the current situation of down fall of the migratory as well as local birds. These effects badly on bird watching tourism in Delhi-NCR. We have noticed other reasons like air pollution, damaging of floodplains and climate change every year. We have suggested some solutions for stopping rapid disappearance of given bird species, solutions for increasing arrival of migratory birds, birds deterrent methods, large cage trapping system and other valuable solutions, so that we can 
save the lives of these colourful and innocent and homeless species. We also agree to the fact that insects eat green leaves of trees and destroy them and birds eat these harmful insects, thus to save the trees we should motivate and follow solutions in order to increase the number of birds.

\section{REFERENCES}

1. http://www.supdelhi.com/5-places-delhi-every-bird-lover-must-visit/

2. https://timesofindia.indiatimes.com/travel/delhi/travel-guide/popular-birdwatchingdestinations-in-and-around-delhi/gs52219233.cms

3. https://obs-up.com/

4. http://www.sanctuaryasia.com/travel/wildlife-destinations/delhi/delhi-ridge.html

5. http://natureconservation.in/sultanpur-national-park-complete-detail-updated/

6. http://surajpurwetland-up.com/biodiversity-status.php

7. https://www.delhiinformation.in/delhi/geography.html

8. https://www.indiatoday.in/mail-today/story/lack-of-wild-birds-in-delhi-hint-at-a-seriousproblem-in-health-of-regions-ecosystem-1119747-2018-01-01

9. https://timesofindia.indiatimes.com/city/delhi/where-have-all-the-sparrows-gone-blameit-on-vanishing-urban-nesting-spaces/articleshow/63372794.cms

10. https://www.dailypioneer.com/2014/delhi/air-pollution-threatens-delhis-wildlifehavens.html

11. https://www.hindustantimes.com/columns/every-vanishing-sparrow-leaves-delhi-moreunliveable/story-1If21m0bbeiNQ5twuk8j2O.html

12. https://birdcount.in/delhi-meetup-2017/

13. https://www.downtoearth.org.in/news/wildlife-biodiversity/how-can-we-bringdisappearing-sparrows-back-to-our-cities--57396

14. https://www.hindustantimes.com/delhi-news/seven-years-on-delhi-s-state-bird-sparrowremains-a-footnote/story-6ZSav3ELSXw5v2tRnDMfMO.html

15. https://www.indiatoday.in/india/story/migratory-birds-flock-to-najafgarh-225735-2014$\underline{11-04}$

16. https://www.indiatoday.in/mail-today/story/delhi-to-get-foreign-help-to-bring-inmigratory-birds-313263-2016-03-15

17. https://birdcount.in/event/big-bird-day/

18. http://indpaedia.com/ind/index.php/Delhi: Birds

19. Chryssoula Chatzigeorgiou, Ioanna Simelli, Apostolos Tsagaris. Bird watching and Ecotourism: An Innovative monitoring system to project the Species of Lesvos Island to Potential Ecotourists. Publ. $7^{\text {th }}$ International conference on information and Communication Technologies in Agriculture, Food and Environment (HAICTA 2015). PP. 452-460. 17-20 September $2015 . \quad$ (http://ceur-ws.org/Vol1498/HAICTA 2015 paper54.pdf)

20. Andersson, C. A Bird watching Database System. Department of Information Technology. PP. 1-26. $2013 . \quad$ December, (http://www.divaportal.org/smash/get/diva2:706189/FULLTEXT01.pdf)

21. Ali, Salim. The Book of Indian Birds. Publ. The Bombay Natural History Society, Bombay.

1941.

PP.

1-394. (https://indiabiodiversity.org/biodiv/content/documents/document-8d97689a-1553-455fa4df-c7cee6821890/486.pdf)

22. Praveen J., Rajah Jayapal and Aasheesh Pittie. A checklist of the Birds of India. Publ. Internet resource. 
(https://www.researchgate.net/publication/305307630_A checklist of the birds of Indi a)

23. Ministry of Environment and Forests. Identification Manual on Birds. (http://www.moef.nic.in/downloads/public-information/Chap-2-new.pdf) 